\title{
BIOLOGICAL EFFECT OF TOMATO JUICE AND PASTE ON HEMOGLOBIN
} DEFICIENCY IN RATS

\author{
By \\ Tesby M. R. Lotfy \\ Home Economics Department, \\ Faculty of Specific Education, Alexandria University,
}

\section{Research gournal Specific Fducation}

Faculty of Specific Fducation

gYansoura University

ISSUE NO. 60, OCTOBER , 2020

مجلة بعوث التربية النوعية - جامعة المنصورة

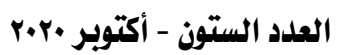




\title{
BIOLOGICAL EFFECT OF TOMATO JUICE AND PASTE ON HEMOGLOBIN DEFICIENCY IN RATS
}

\author{
Tesby M. R. Lotfy *
}

\section{Abstract}

Tomato is a good source Phytochemicals and it may be important owning to their paternal use in traditional medicine. Anemia in association With iron deficiency has serious implications in long terms. The Study aimed to evaluate the effect of tomato Juice and Paste alone or with phenylhydrazine (PHZ) on the levels of hemoglobin ( $\mathrm{Hb})$, Red blood cells( RBCs) and White blood cells (WBCs) also effect on the levels of Thiobarbituric acid reactive substances (TBARS), glutathione reduced (GSH), the activities of antioxidant enzymes and lipid profile of male rats 36 male rats were assigned to Six groups for (4) weeks. Feeding period, group (1) -ve control, group (2) treated with juice, group (3) treated with paste, group (4) treat with PHZ, + ve control, group (5) treated with combination of PHZ and juice, group (6) treated with combination of Phz and Paste . Results showed that consumption of Tomato juice and paste group showed improvement of hemoglobin values and had significant decrease in serum lipid profile and Thiobarbituric acid reactive substances (TBARS). Moreover, they showed significant increase in hemoglobin, blood picture and Antioxidant enzymes such as superoxide dismutase, glutathione-peroxidase ,catalase and glutathione S-transferase, compared with control +ve group. The best treatment effect of anemia injured rats group appeared in Tomato juice or paste groups. These results may be attributed to nutritional component and antioxidant activity of Tomato juice and paste. In conclusion, feeding rats with Tomato juice and paste may significantly reduce anemic.

Key words, tomato, $\mathrm{PHz}, \mathrm{CBC}$, antioxidant enzymes, lipid profile, anemia, rats .

* Home Economics Department, Faculty of Specific Education, Alexandria University, 


\section{Introduction}

Anemia is defined as a condition in which the number of red blood cells (RBCs) or their oxygen-carrying capacity Anemia is defined as a condition in which the number of red blood cells (RBCs) or their oxygencarrying capacity is insufficient to meet the physiological needs of the body. There are over 400 types of anemia ,many of which are rare, but in all cases, there is lower than a normal number of circulating RBCs. Many types of anemia exist such as iron deficiency anemia, pernicious anemia, hemolytic anemia, aplastic anemia, megaloblastic anemia, and sickle cell anemia, thalassemia, and sideroblastic anemia. Iron deficiency is thought to be the most common cause of anemia globally (Kassebaum et al., 2014). The causes of anemia can be acquired or inherited. Other factors such as lack of access to balance diet, folate, Vitamin B12, Vitamin A deficiencies, chronic inflammation, infection, and inherited disorders can cause anemia (Moll and Davis, 2017). Anemia occurs, and the body makes few RBCs, destroys many RBCs, or loses many RBCs. Iron deficiency anemia has serious consequences for the health and well-beings as well as the social and economic impact of India (Stoltzfus, 2003). Iron, folic acid, and vitamin deficiency anemia can be treated with changes in diet plan with the supplementation iron, folic acid, and vitamin .Tomatoes, which are actually a fruit and not a vegetable, are loaded with all kinds of health Benefits for the body. They are in fact, a highly verBStile health product and due to their equally VerBStile preparation options, there's really no reason to neglect the tomato as part of a healthy diet. One of the most well-known tomato eating benefit is its' Lycopene content. Lycopene is a Vital anti-oxidant that helps in the fight against cancerous cell formation as well as other kinds of health complications and diseases. Free radicals in the body can be flushed out with high levels of Lycopene, and the tomato is so amply loaded with this vital anti-oxidant that it actually derives its rich redness from the nutrient. There are known different varieties of tomato, round, oval, "cherry", but all have the BSme nutritional characteristics, being an important source of: - potassium, phosphorus, magnesium, iron, so necesBSry to the normal activity of nerves and muscles; (PraBSd et al., 2018). 
- vitamins as A, B and C - tomatoes is the third source of vitamin C in our diet and the fourth for vitamin A, through its content in beta-carotene or pro vitamin A;.Phytosterols, compounds that help to keep cholesterol under control,the folic acid, which helps eliminate homocysteine, an amino acid whose metabolism is dependent on the metabolism of vitamins from B complex, especially that of folic acid. This is pretty powerful evidence that the health benefits of eating a tomato are really quite phenomenal. It takes as little as 540 milliliters of liquid tomato product to get the full Benefits of Lycopene. This means that a daily glass of tomato juice has the potential to keep a Person healthy for life. Tomatoes are equally as nutritious fresh as they are in other variable forms. When tomato products are heat processed the bioavailability of the Lycopene actually Increases rather than the anticipated decrease. Even with all the plentiful research that has gone Into the health benefits of tomatoes, there is still more research being conducted as the medicalScience community understands that we have not fully tapped into the potential presented by a Tomato just yet. Research is now slowly proving that there is a high likelihood that the consumption of tomatoes and tomato b .Phenylhydrazine Hydrochloride is on the Breathing Phenylhydrazine hydrochloride can irritate the nose, throat and lungs causing, wheezing or shortness of breath. Phenylhydrazine hydrochloride may damage the liver and kidneys. There is limited evidence that Phenylhydrazine Hydrochloride causes cancer in animals. It may cause leukemia (Periago et al., 2008)

Therefore, the present study was designed to the effect of Tomato juice and paste on the anemia in rats .

\section{Introduction}

\section{MATERIALS AND METHODS}

Thirty six adult male albino rats Sprague-Dawley weighing 100-200 $\mathrm{g}$ were purchased from ----------, Egypt. The baBSl diet consisted of protein $(13 \%)$, fat $(4 \%)$, BSlt mixture (3.5\%), vitamin mixture $(1 \%)$, choline $(0.2 \%)$, cellulose (5\%) and the remainder was starch (Reeves et al., 1993). Tomato juice and paste were obtained from local markets in Alexandria, 
Egypt. phenylhydrazine (PHZ) was obtained from El-Gomhorya Company for Chemical and Pharmaceutical, Alexandria, Egypt .Kits for biochemical analysis were purchased from the Gamma Trade Company for Pharmaceutical and Chemicals, Dokki, Egypt

\section{Experimental design:}

The experimental rats were divided into six groups after adaptation period (one week). The animals had been maintained under standard conditions (room temperature $25^{\circ} \mathrm{C} \pm 3$, humidity $35-60 \%$, and light and dark period 12/12 h) (Childs et al., 2002). All animals were fed with food and water and libitum. The study protocols were duly approved by the Institutional Animal Ethics Committee of the institute, MES Medical College, Perinthalmanna. The study was performed in accordance with the CPCSEA guidelines. The first group which kept as control (-ve) group ( $\mathrm{n}=6$ rats) which fed on baBSl diet only. The second group was consumed of Tomato Juice alone added to water $5 \mathrm{ml}$. / kg. (BWt.) The third group was consumed of Tomato BSla alone by gavage $5 \mathrm{ml}$. /Kg. (BWt). The fourth, fifth and sixth rats group were administered phenylhydrazine (PHZ) at a two dose of $40 \mathrm{mg} / \mathrm{kg}$ by intraperitonea to induce anemia for 2 days (D0 and $\mathrm{D} 1)$. On the 2 day, hemoglobin ( $\mathrm{Hb})$ level of treated rats is estimated, and the treated rat with $\mathrm{PHZ}$ whose $\mathrm{Hb}$ concentration $<13 \mathrm{~g} / \mathrm{dl}$. Was considered as anemic and included in this study(Diallo et al., 2008 and Koffuor et al., 2011). . Anemic rats were classified into three groups . The fourth group positive control (anemia) were consumed the baBSl diet. The fifth rats group were treated with Tomato juice $(5 \mathrm{ml}$. $/ \mathrm{Kg}$.) The sixth rats group were treated with Tomato BSla $(5 \mathrm{ml}$. $/ \mathrm{Kg}$.) The study was assigned for $\varepsilon$ weeks

\section{Analysis of Hematological Parameters}

After 4 weeks of treatment, a whole blood BSmple was collected from retro-orbital plexus under anesthesia. The number, shape, volume, and the color of the RBCs indicate the quality of blood (Jaiswal et al., 2014).

At the end of the experiment, the rats were BScrificed to obtain blood BSmples. Part of blood was heparenized while the rest part of blood 
$\overline{\underline{ }}$ r.r. مجلة بحوث التربية النوعية - عدد •r - أكتوير

was left to coagulate then centrifuged at $3000 \mathrm{rpm}$ for 15 minutes to obtain serum for each individual BSmple and then stored at $-20{ }^{\circ} \mathrm{C}$ for some laboratory analyses

\section{Determination of some blood biochemical parameters:}

i. Red blood cell counts (RBC) and white blood cells were determined as described by Brown (1976). The

hemoglobin (Hb) concentration (determined using cyanomethaemoglobin method) were as described by Hewitt (1984).

ii. Hematological indices such as mean corpuscular hemoglobin concentration (MCHC) were calculated from determined values of PCV, RBC and Hb as described by Schalm et al., (1975).

\section{Determination of some serum biochemical parameters:}

iii. Serum triglycerides (T. G) were measured using the modified kinetic method according to the method described by FosBSti and Principe (1982).

iv. Serum cholesterol was measured using the modified kinetic method according to Richmond (1973).

vi. high density lipoprotein cholesterol (HDL-c) was measured using the modified Kinetic method according to Allain (1974).

v. Low density lipoprotein cholesterol (LDL-c) was calculated as $\mathrm{mg} / \mathrm{dl}$. According to Castelli et al., (1977) equation:

LDL Concentration mg/dl. =TC-(VLDL + HDL)

i. Very low-density lipoprotein cholesterol (VLDL-c): Serum very low-density lipoprotein cholesterol (VLDL-c) was calculated as $\mathrm{mg} / \mathrm{dl}$. According to Lee and Nieman (1996) equation:

$$
\text { VLDL-c Concentration mg/dl. }=\frac{T . G}{5}
$$

3. Estimation of antioxidant enzyme activity .

The activity of superoxide dismutase (SOD) was asBSyed by the method of Kakkar et al., (1984). 
The activity of glutathione peroxidase was asBSyed by the method of Rotruck et al., (1973).

The catalase activity determined by Goth's colorimetric method, in which serum was incubated in $\mathbf{H 2 O 2}$ substrate and the enzymatic reaction stopped by the addition of ammonium molybdate (Goth,1991).

Thiobarbituric acid reactive substances (TBARS) was asBSyed by the method of Tappel and Zalkin (1959)

\section{Statistical analysis of data}

All the obtained data were statistically analyzed by SPSS computer soft ware. The calculated occurred by analysis of variance ANOVA and follow up test LSD by SPSS ver.11 according to Artimage and Berry (1987).

\section{Result and discussion:}

1. Table (1) shows Concerning HB, RBCs and MCHC it could be observed that the rats in control Positive group (anemic rats which received diets with Tomato Juice or Tomato Paste) had a significant lower means values $(\mathbf{P}<\mathbf{0 . 0 5})$ than that of control negative group as the following $(5.40 \pm 0.46,4.73 \pm 0.46$ and $6.74 \pm 0.67$ Vs. $7.91 \pm 0.01,6.76$ \pm 0.67 and $7.80 \pm 0.0$ respectively). Concerning WBCs it could be observed that the rats in control Negative group had a significant lower means values $(\mathbf{P}<\mathbf{0 . 0 5})$ than that of control Positive group as the following $(21.0 \pm 0.34$ Vs. $35.80 \pm 0.15$ respectively). Rats which received diets with Tomato Paste or Tomato Juice had more mean values of HB , RBCs and MCHC compared with control positive group. On the other hand, the BSme treated groups of rats had higher mean values of WBCs than that of the control Positive group. The best result of HB was noticed in the group of rats fed on Tomato Paste, followed by group that treated with Tomato Juice. Tomatoes contain vitamin c which can be used as a therapy of non-pharmacological in fixing the status of anemia (HadiBSputro and Hidajati 2016). Eating strawberry juice and tomato juice can also increase hemoglobin levels. But giving tomato juice is more effective than strawberry juice (Wulandari et al., 2017). Previous 
research explains that combination therapy of spinach and tomato juice is effective against increasing hemoglobin levels in pregnant women (Meriada et al., 2009).

Table (1): Mean values \pm SD of blood $\mathrm{HB}, \mathrm{RBC}, \mathrm{MCHC}$ and WBCs of the experimental rats groups.

\begin{tabular}{|c|c|c|c|c|c|c|c|c|}
\hline & $\begin{array}{c}\text { Control (-) } \\
(n=6) \\
\end{array}$ & $\begin{array}{c}(T-) \\
(n=6)\end{array}$ & $\begin{array}{c}(\mathrm{BS}-) \\
(\mathrm{n}=6)\end{array}$ & $\begin{array}{c}\text { Control+ } \\
(n=6)\end{array}$ & $\begin{array}{c}T+ \\
(n=6) \\
\end{array}$ & $\begin{array}{c}\text { BS+ } \\
(n=6)\end{array}$ & $\mathbf{F}$ & $\mathbf{p}$ \\
\hline HB & $7.91 d \pm 0.01$ & $\begin{array}{c}8.73 \mathrm{c} \pm \\
0.34\end{array}$ & $\begin{array}{c}9.91 \mathrm{a} \pm \\
0.32\end{array}$ & $\begin{array}{c}5.40 \mathrm{e} \pm \\
0.46\end{array}$ & $\begin{array}{c}8.44 c \pm \\
0.67\end{array}$ & $\begin{array}{c}9.39 b \pm \\
0.47\end{array}$ & $110.078^{*}$ & $<0.001 *$ \\
\hline RBC & $6.76 a \pm 0.67$ & $\begin{array}{c}4.62 \mathrm{~d} \pm \\
0.04\end{array}$ & $\begin{array}{c}5.36 \mathrm{c} \pm \\
0.08\end{array}$ & $\begin{array}{c}4.73 d \pm \\
0.46\end{array}$ & $\begin{array}{c}5.89 b \pm \\
0.13\end{array}$ & $\begin{array}{c}5.73 b c \pm \\
0.40\end{array}$ & $26.756^{*}$ & $<0.001 *$ \\
\hline MCHC & $7.80 \mathrm{a} \pm 0.0$ & $\begin{array}{c}6.24 b \pm \\
0.54\end{array}$ & $\begin{array}{c}5.58 \mathrm{c} \pm \\
0.54\end{array}$ & $\begin{array}{c}6.74 b \pm \\
0.67\end{array}$ & $\begin{array}{c}7.99 a \pm \\
0.28\end{array}$ & $\begin{array}{c}8.03 a \pm \\
0.24\end{array}$ & $32.769 *$ & $<0.001 *$ \\
\hline WBCs & $21.0 \mathrm{~d} \pm 0.34$ & $\begin{array}{c}18.01 f \pm \\
0.20\end{array}$ & $\begin{array}{c}19.80 \mathrm{e} \pm \\
0.31\end{array}$ & $\begin{array}{c}\text { 35.80a } \pm \\
0.15\end{array}$ & $\begin{array}{c}23.80 b \pm \\
0.32\end{array}$ & $\begin{array}{c}22.60 \mathrm{c} \pm \\
0.30\end{array}$ & $3105.562 *$ & $<0.001 *$ \\
\hline
\end{tabular}

F: F for ANOVA test $\quad$--- $\quad \mathrm{T}=$ tomato juice, BS tomato past

$\mathrm{p}$ : $\mathrm{p}$ value for comparing between the studied groups

*: Statistically significant at $\mathrm{p} \leq 0.05$

Means with Common letters are not significant (i.e. Means with Different letters are significant)

2. Effect of Tomato Juice and Tomato Paste on Antioxidant of anemic Rats.

Table (2) shows Concerning Glutathione (GSH), Glutathione Transferases (GST), Catalase (CAT), Glutathione Peroxidase (GPx) and Superoxidase dismutase (SOD) . it could be observed that the rats in control negative group had a significant more means values $(\mathbf{P}<\mathbf{0 . 0 5})$ than that of control Positive group (anemic rats) which received diets with Tomato Juice or Tomato Paste as the following $(\mathbf{5 0 . 5 0} \pm \mathbf{0 . 2 5}, \mathbf{0 . 7 6} \pm \mathbf{0 . 0 3}$, $50.73 \pm 0.19,1.50 \pm 0.04$ and $15.63 \pm 0.11$ Vs. $21.50 \pm 0.19,0.38 \pm 0.01$, $23.77 \pm 0.02,0.40 \pm 0.24$ and $6.39 \pm 0.08$ Respectively.), with Concerning Thiobarbituric acid reactive substances (TBARS) it could be observed that the rats in control Negative group had a Significant lower means Values 
$(\mathbf{P}<\mathbf{0 . 0 5})$ than that of Control Positive group (anemic rats) which received diets with Tomato Juice or Tomato Paste as the following ( $1.89 \pm 0.18$ Vs. $\mathbf{2 . 5 7} \pm \mathbf{0 . 4 3}$ respectively ). Rats which received diets with Tomato Paste or Tomato Juice had lower mean values of Glutathione (GSH), Glutathione Transferases (GST), Catalase (CAT), Glutathione Peroxidase (GPx) and Superoxidase dismutase (SOD) Compared with control positive group. On the other hand, the BSme treated groups of rats had higher mean values of Thiobarbituric acid reactive substances (TBARS) than that of the control Positive group. The best result of Antioxidants was noticed in the group of rats fed on Tomato Paste, followed by group that treated with Tomato Juice. Tomato contain a variety of phytochemical, such as lycopene , flavonoids, glycosides and other chemical constituents that have been beneficial protective effect. the study of Humaish (2016) revealed that administration of $0.75 \% \mathbf{H 2 O 2}$ in drinking water (groupI) produced significant decline of antioxidant enzymes superoxide dismutase (SOD), glutathione (GSH), catalase (CAT) ) . On the other hand the animals treated with $\mathbf{H 2 O 2}$ plus $4 \mathrm{mg} / \mathrm{kg} \mathrm{BW}$ of tomato extract (groupIII) showed significant increase of SOD, GSH, comparing with control group. Depending on the above oxidant and antioxidant markers, it seems that 4 $\mathrm{mg} / \mathrm{kg}(\mathrm{BW})$ of tomato extract exert beneficial action protect against $\mathbf{H 2 O 2}$ induced oxidative stress in rats. 
مجلة بحوث التربية النوعية - عدد •r - r.r. أكتوير

Table (2): Mean values \pm SD of glutathione peroxidase (GSH,) glutathione transferase(GST), Thiobarbituric acid reactive substances (TBARS),catalase, (CAT), superoxid dismutase (SOD), and glutathione peroxidase (GPX) of the experimental rats groups.

\begin{tabular}{|c|c|c|c|c|c|c|c|c|}
\hline & $\begin{array}{l}\text { Control (-) } \\
\qquad(\mathrm{n}=6)\end{array}$ & $\begin{array}{c}(T-) \\
(n=6)\end{array}$ & $\begin{array}{c}(\mathrm{BS}-) \\
(\mathrm{n}=6)\end{array}$ & $\begin{array}{c}\text { Control+ } \\
(n=6)\end{array}$ & $\begin{array}{c}T+ \\
(n=6)\end{array}$ & $\begin{array}{c}\text { BS+ } \\
(n=6)\end{array}$ & $\mathbf{F}$ & $\mathbf{p}$ \\
\hline GSH (U/ml) & $50.50^{\mathrm{c}} \pm 0.25$ & $56.90^{\mathrm{b}} \pm 0.67$ & $69.40^{\mathrm{a}} \pm 0.12$ & $21.50^{\mathrm{f}} \pm 0.19$ & $43.70^{\mathrm{e}} \pm 0.34$ & $49.60^{d} \pm 0.39$ & $11023.11^{*}$ & $<0.001^{*}$ \\
\hline GST (mmol /ml) & $0.76^{\mathrm{abc}} \pm 0.03$ & $0.98^{\mathrm{a}} \pm 0.06$ & $0.83^{\mathrm{ab}} \pm 0.62$ & $0.38^{\mathrm{d}} \pm 0.01$ & $0.51^{\mathrm{cd}} \pm 0.02$ & $0.59^{\text {cd }} \pm 0.08$ & $4.436^{*}$ & $0.004^{*}$ \\
\hline TBARS & $1.89^{\mathrm{b}} \pm 0.18$ & $1.37^{\mathrm{c}} \pm 0.21$ & $1.35^{\mathrm{c}} \pm 0.07$ & $2.57^{\mathrm{a}} \pm 0.43$ & $2.04^{\mathrm{b}} \pm 0.09$ & $2.05^{\mathrm{b}} \pm 0.06$ & $27.650^{*}$ & $<0.001^{*}$ \\
\hline $\operatorname{CAT}(\mathrm{u} / \mathrm{min} / \mathrm{ml})$ & $50.73^{\mathrm{c}} \pm 0.19$ & $72.87^{\mathrm{a}} \pm 0.07$ & $65.50^{\mathrm{b}} \pm 0.52$ & $23.77^{\mathrm{f}} \pm 0.02$ & $47.63^{\mathrm{d}} \pm 0.26$ & $42.58^{\mathrm{e}} \pm 0.79$ & $1082.75^{*}$ & $<0.001^{*}$ \\
\hline SOD $(\mathbf{u} / \mathbf{m l})$ & $1.50^{\mathrm{b}} \pm 0.04$ & $1.96^{\mathrm{a}} \pm 0.55$ & $2.10^{\mathrm{a}} \pm 0.60$ & $0.40^{\mathrm{d}} \pm 0.24$ & $1.01^{\mathrm{c}} \pm 0.07$ & $1.26^{\mathrm{bc}} \pm 0.10$ & $19.557^{*}$ & $<0.001^{*}$ \\
\hline GPX (u/ml) & $15.63^{c} \pm 0.11$ & $21.83^{b} \pm 0.49$ & $22.87^{\mathrm{a}} \pm 0.21$ & $6.39 \pm 0.08$ & $11.16 \pm 0.71$ & $14.98 \pm 0.53$ & $1295.84^{*}$ & $<0.001^{*}$ \\
\hline
\end{tabular}

F: F for ANOVA test $\quad T=$ tomato juice, BS tomato past

$\mathrm{p}$ : $\mathrm{p}$ value for comparing between the studied groups

*:Statistically significant at $\mathrm{p} \leq 0.05$

Means with Common letters are not significant (i.e. Means with Different letters are significant)

\section{Effect of Tomato Juice and Tomato Paste on Lipid Fractions of anemic Rats:}

Table (3) shows Concerning Total Lipids, Serum Cholesterol, Triglycerides, LDL-c and VLDL-c (mg/dl.). it could be observed that the rats in control negative group had a significant lower means values $(\mathbf{P}<\mathbf{0 . 0 5})$ than that of control Positive group (anemic rats) which received diets with Tomato Juice or Tomato Paste as the following $(\mathbf{5 0 3 . 2 8} \pm \mathbf{0 . 3 0}, \mathbf{1 5 0 . 4 9} \pm \mathbf{0 . 7 9}$ , $125.65 \pm 0.49,57.48 \pm 0.59$ and $67.88 \pm 0.10 \mathrm{mg} / \mathrm{dl}$. Vs. $655.10 \pm 0.52$, $197.64 \pm 0.56,157.39 \pm 0.78,127.89 \pm 0.26$ and $31.48 .16 \mathrm{mg} / \mathrm{dl}$. Respectively. The Percentage of increase in Cholesterol value was $31.33 \%$, while HDL-c value (mg/dl.) for control Positive group decreased than that of the control negative group by about $33.4 \%$. Addition of Tomato Juice or Tomato Paste to the diet of anemic rats either in a significant reduction 
$(\mathbf{P}<\mathbf{0 . 0 5})$ in Cholesterol values $(\mathbf{1 7 5 . 0 6} \pm .0 .06$ Vs169.42 $\pm 0.06 \mathrm{mg} / \mathrm{dl}$. $)$ respectively. Rats which received diets with Tomato Paste or Tomato Juice had lower mean values of Total Lipid (TL), Triglycerides (TG), LDL-C and VLDL-c compared with control positive group. On the other hand, the BSme treated groups of rats had higher mean values of LDL-c than that of the control Positive group. The best result of lipid fractions was noticed in the group of rats fed on Tomato Paste, followed by group that treated with Tomato Juice. Scientists have shown that consumption of antioxidants can reduce hypercholesterolemia and proved benefits of fruit and vegetables. Tomato reduces oxidative stress by increasing serum total antioxidant level (Nouri and Rezapour, 2011).Our result are in agreement with many studies which showed that, the tomato decreased amount of Total Cholesterol, LDL-c and Triglycerides and increased HDL-c levels(Nouri and Rezapour , 2011) . Studying of Ibrahim et al.,(2008) on three different tomato products including powder, paste and tomato catchup paste and compare their effects on body weight, lipid profiles, liver enzymes and the atherogenic index of rats reported that these three products have significantly beneficial therapeutic effects in rats and beneficial effects were most related to the tomato paste and catchup paste relatively. Blum et al.,(2006) in a study on 32 women and 16 men for one month with high tomato $(300 \mathrm{~g}$ daily)diet showed that diet significantly increased $(\mathbf{P}<\mathbf{0 . 0 5})$ serum HDL (15.2 \%). They also reported that cholesterol, triglyceride, LDL and VLDL decreased, but these changes were not significant. Studied the effects of dried tomato on rats, tomato decreased $15 \%$ of cholesterol (Bobek et al., 1998). 


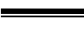
r.r. مجلة بحوث التربية النوعية - عدد م4 - أكتوير

Table (3): ): Mean values \pm SD of serum lipid parameters of the experimental rats groups.

\begin{tabular}{|ccccccccc||}
\hline \hline & $\begin{array}{c}\text { Control }(-) \\
(\mathbf{n}=\mathbf{6})\end{array}$ & $\begin{array}{c}(\mathbf{T}-) \\
(\mathbf{n}=\mathbf{6})\end{array}$ & $\begin{array}{c}(\mathbf{B S}-) \\
(\mathbf{n}=\mathbf{6})\end{array}$ & $\begin{array}{c}\text { Control+ } \\
(\mathbf{n}=\mathbf{6})\end{array}$ & $\begin{array}{c}\mathbf{T}+ \\
(\mathbf{n}=\mathbf{6})\end{array}$ & $\begin{array}{c}\mathbf{B S}+ \\
(\mathbf{n}=\mathbf{6})\end{array}$ & $\mathbf{F}$ & $\mathbf{p}$ \\
\hline TL & $503.28^{\mathrm{d}} \pm 0.30$ & $439.37^{\mathrm{e}} \pm 0.64$ & $425.60^{\mathrm{f}} \pm 0.26$ & $655.10^{\mathrm{a}} \pm 0.52$ & $564.48^{\mathrm{b}} \pm 0.56$ & $550.68^{\mathrm{c}} \pm 0.66$ & $16783.38^{*}$ & $<0.001^{*}$ \\
Chol & $150.49^{\mathrm{d}} \pm 0.79$ & $130.14^{\mathrm{e}} \pm 0.15$ & $127.22^{\mathrm{f}} \pm 0.41$ & $197.64^{\mathrm{a}} \pm 0.56$ & $175.06^{\mathrm{b}} \pm 0.20$ & $169.42^{\mathrm{c}} \pm 0.60$ & $17792.8^{*}$ & $<0.001^{*}$ \\
TG & $125.65^{\mathrm{d}} \pm 0.49$ & $98.71^{\mathrm{e}} \pm 0.63$ & $96.70^{\mathrm{f}} \pm 0.68$ & $157.39^{\mathrm{a}} \pm 0.78$ & $146.94^{\mathrm{b}} \pm 0.21$ & $135.94^{\mathrm{c}} \pm 0.09$ & $1284.20^{*}$ & $<0.001^{*}$ \\
HDL-C & $57.48^{\mathrm{c}} \pm 0.59$ & $68.61^{\mathrm{b}} \pm 0.67$ & $75.61^{\mathrm{a}} \pm 0.39$ & $38.27^{\mathrm{f}} \pm 0.67$ & $44.87^{\mathrm{e}} \pm 0.06$ & $49.06^{\mathrm{d}} \pm 0.61$ & $4203.54^{*}$ & $<0.001^{*}$ \\
LDL-C & $67.88^{\mathrm{d}} \pm 0.10$ & $41.79^{\mathrm{e}} \pm 0.65$ & $32.27^{\mathrm{f}} \pm 0.11$ & $127.89^{\mathrm{a}} \pm 0.26$ & $100.80^{\mathrm{b}} \pm 0.11$ & $93.17^{\mathrm{c}} \pm 0.02$ & $93349.52^{*}<0.001^{*}$ \\
VLDL-C & $25.13^{\mathrm{d}} \pm 0.10$ & $19.74^{\mathrm{e}} \pm 0.13$ & $19.34^{\mathrm{f}} \pm 0.14$ & $31.48^{\mathrm{a}} \pm 0.16$ & $29.39^{\mathrm{b}} \pm 0.04$ & $27.19^{\mathrm{c}} \pm 0.02$ & $12819.56^{*}<0.001^{*}$ \\
\hline \hline
\end{tabular}

F: F for ANOVA test $\quad T=$ tomato juice, BS tomato past

$\mathrm{p}$ : $\mathrm{p}$ value for comparing between the studied groups

*: Statistically significant at $\mathrm{p} \leq 0.05$

Means with Common letters are not significant (i.e. Means with Different letters are significant)

\section{References:}

1. Allain, C.C. (1974): Cholestrol enzymatic colorimetric method. J. of Clin. Chem;20: 470.

2. Artimage, G.Y and Berry, W.G. (1987): Statistical Methods 7th Ed. Ames, Iowa Stata University Press, 39-63

3. Blum A. M., Merei A. Karem N. Blum S., Ben-Arzi I. and WirBSnsky (2006): Effects of tomatoes on the lipid profile. Clin invest Med.29(5),298300.

4. Bobek P. L. Ozdin M., and Hromadova (1998): The effect of dried tomato, grape and apple Pomace on the cholesterol metabolism and antioxidative enzymatic system in rats with hypercholesterolemia. Nahrung.42(5),317-320.

5. Brown B. A. (1976): Textbook of Hematology Principle Procedures. 2nd edition. Lea and Febiger. Philadelphia. UBS, 56-8.1.

6. Castelli, W. P.; Doyle, J. T.; Gordon, T.; Hames, C. G.; Hjortland, M. C.; Halley, S. B.; Kagan, A. and Zuckel, W. J. (1977): HDL cholesterol and other lipids in coronary heartdisease: The cooperative lipoprotein phenotyping study.Circulation, 55: 767-772. 
- Biological effect of tomato juice and paste on hemoglobin deficiency in rats

7. Childs A. C., Phaneuf S. L., Dirks A. J., Philips T. and Leeuwenburgh C. (2002): Doxorubicin treatment in vivo causes cytochrome $\mathrm{C}$ release and cardiomyocyte apoptosis dismutase activity and Bcl-2: Bax ratio. Cancer Res.62,4592-4598.

8. Diallo A. Gbeassor M., Vovor A., Eklu-Gadegbeku K. Aklikou K. and Agbonon A. (2008): Effect of Tectona grandis on Phenylhydrazine induced anemia in rats . Fitoterapia ,79,332-336.

9. FosBSti P. and Principe L. (1982): Determination of triglycerides Clinical chemistry, 28:2077-2078.

10. Goth, L. (1991): A simple method for determination of serum catalase activity, and revision of reference range. ClinChim.Acta,196:143-52.

11. HadiBSputro S. S. and Hidajati K. (2016): Tomato fruit Extract improves the levels of hemoglobin (HB) in pregnant women the anemia who get $\mathrm{Fe}$ supplementation. International Journal of Science and Research (IJSR), 7(9),447-450.

12. Hewitt S. G.(1984): Manual for Veterinary Investigation, hematology and Laboratory techniques. 3rd edtion. Bulleting of Ministry of Agric. Fishery, Food and Hematology, 77-79.

13. Humaish H. H. (2016): Study the Antioxidant effect of tomato extract in oxidative stressed Rats. Bas.J.Vet.Res.15(1),66-80.

14. Ibrahim H. S., Ahmed M. and El-din M. (2008): The functional role of some tomato products on lipid profile and liver function in adult rats. J Med Food, 11(3),551-559.

15. Jaiswall A., Ganeshpurkar A., Awasthi A., BanBSI D. and Dubey N. (2014): Protective Effects of Beetroot Extract against Phenyl Hydrazine Induced Anemia in Rats. Phcog J.6(5).

16. Kakkar P., Das B. and Viswanathan, P. N. (1984): A modified spectrophotometric asBSy of superoxide dismutase. Indian J. of Biochemistry and Biophysics,(21):130-132.

17. Kassebaum N. J., JasraBSria R., Naghavi M., Wulf S. K., Johns N., and Lozano R., (2014): A systematic analysis of global anemia burden from 1990 to 2010 . Blood ,123:615-24. 
18. Koffuor G. A., Amoateng P., and Andey T. A. (2011): Immunomodulatory and erythropoietic eefects of aqueous extract of the fruit of Solanum torvum Swartz (Solanaceae).Pharmacognosy Res,3:130-134.

19. Lee R. and Nieman D. (1996): Nutrition Assessment. 2nd Ed.13. Mosby, Missouri, UBS. 591-594.

20. Meriada N., and Utomo W. (2009):Effectiveness of juice combination therapy spinach and tomatoes to increase levels hemoglobin in pregnant women with anemia 1,1-9.

21. Moll R., and Davis B.(2017): Iron, vitamin B12 and folate. Medicine;45:198-203.

22. Nouri K. H. and Rezapour K. A. (2011): Effect of tomato supplementation on the level of srum lipids and lipoprotein in Rats fed with high cholesterol. Advanced in Environmental Biology, 5(9),3036-3041.

23.Periago MJ, Jacob K,and Boehm V.( 2008) Influence of lycopene and vitamin $\mathrm{C}$ from tomato juice on biomarker of oxidative stress and inflammation. $\mathrm{Br} \mathrm{J}$ Nutr; 99:137-146

24 PraBSd S., Hari P., Shajina M., Mirshad P. V. and Rahiman F. (2018): Hematinic and antioxidant potential of aqueous extract of SeBSmum indicum seeds against phenylhydrazine-induced hemolytic anemia in albino rats. National Journal of Physiology, Pharmacy and Pharmacology,8(8), 10921096.

25.Reeves D.W., Mask P.L., Wood, C. W. and Delaney D.P. (1993): Determination of wheat nitrogen status with a hand-held chlorophyll meter: Influence of management practices. J. Plant Nutri.,109 (16): 781-796.

26.Richmond W. (1973): Preparation and properties of a cholesterol oxidase from Nocardia sp. and its application to the enzymatic asBSy of total cholesterol in serum. Clin.Chem., 19 (12): 1350.

27 .Rotruck J. T.,Pope L., Ganther H. E. and Swanson A. B. (1973): Selenium biochemical role as a component of glutathione peroxidase. Science, 179:588.

28 Schalm, O. W. ; Jain, N. C. ; and Carroll, E. J. (1975) Book : Veterinary hematology. 1975 No.3rd edition pp.xi +807pp. 
28. Stoltzfus R. J. (2003): Iron deficiency: Global prevalence and consequences. Food Nutr Bull,244(2),:S99-103.

29. Tappel, A.L. and Zalkin, H. (1959): Inhibition of lipid peroxidation in mitochondria by vitamin E. Archives of Biochemistry and Biophysics 80: 333336

30. Wulandari S., Dewi N. A., and Afriliana F. D. (2017): Internationl Journal of medical research and pharmaceutical sciences comparison of effectivity from consumption tomato juice and strawberry juice against level of haemoglobin in third trimester of pregnant women, 4:42-54. 


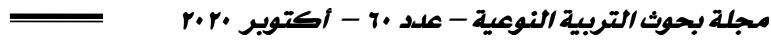

\section{التأثير البيـولوجي لهصير وهمجون الطماطم على نقص الهيسموجلوبين في الفئران}

الالخص العربي

تعتبر الطماطم مصدرًا جيدًا للمركبات النشطة حيويا وقد يكون من المهم وجودها

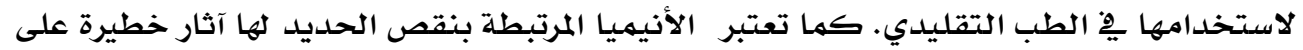

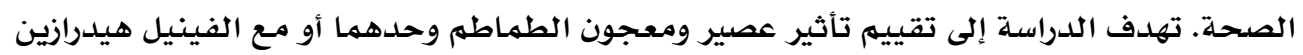

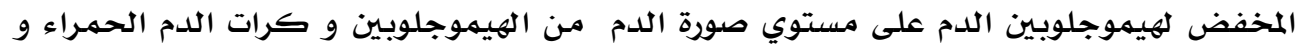

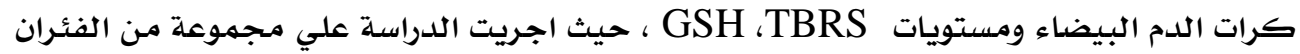

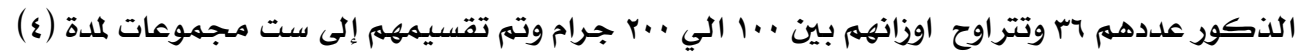

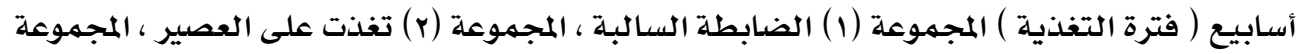

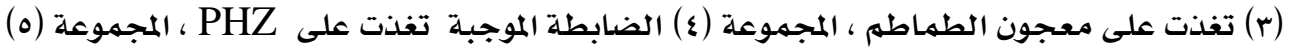

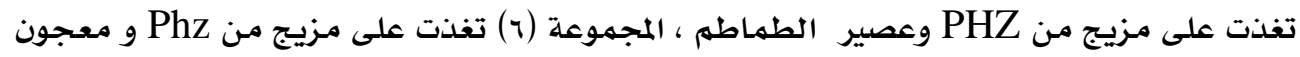

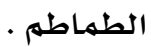

واسفرت النتائج المتحصل عليها أن استهلاك مجموعة عصير الطماطم أظهر تحسنًا

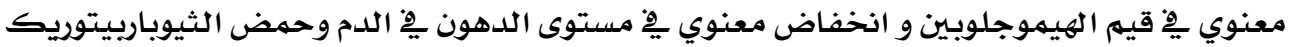

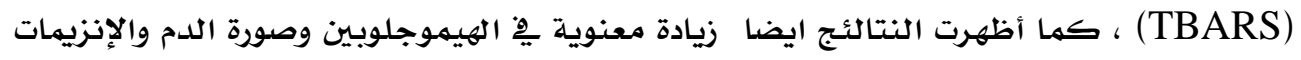

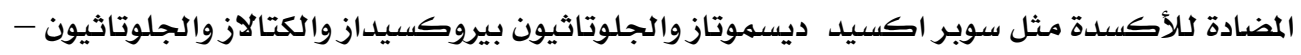

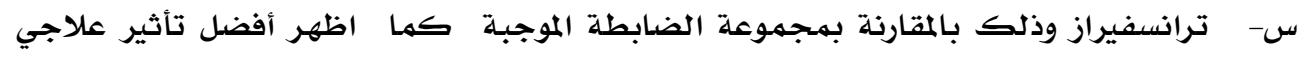

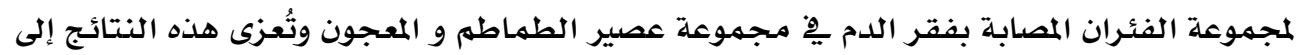

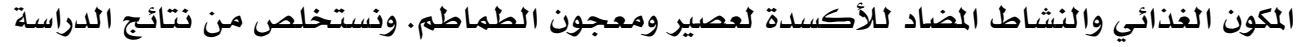

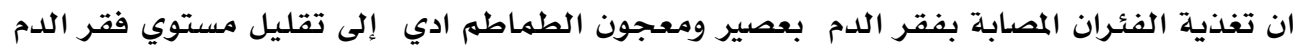
بشكل كبير بِّ الفئران الكلمات الأساسية : إنزيمات مضادات الأكسدة ، الفينيل هيدرازين ، الطماطم ، الدهون

الانيميا -الفئران 